\title{
Justification of public investment initiatives on water transfer systems as an instrument for water balances in Spain: the case of the Júcar-Vinalopó water transfer system
}

\author{
Martin Sevilla*, Teresa Torregrosa* \\ Applied Economic Department, Water Institute, University of Alicante, Alicante, Spain; \\ *Corresponding Author: martin.sevilla@ua.es, teresa.torregrosa@ua.es
}

Received 5 September 2011; revised 16 October 2011; accepted 23 October 2011.

\begin{abstract}
One of the most controversial issues in recent years in water management has been finding a balance between available resources and water needs related to certain territories. The changes brought about by a new awareness over the need to preserve the environment, the social perception of the ownership of the river channels, the need for adjust financial costs arising from the waterworks and the compliance with European standards urgently require redesign of water supply policies in force at this time. The Júcar-Vinalopó water transfer, considered as an historic aspiration for many years in the region, has been regarded as a key element for solving the depletion of groundwater in a large area located in the southeast of the Iberian Peninsula, mainly for irrigation purposes. In this paper we present an approach to the economic aspects related to the implementation of the project, its investment and financing arrangements and the question of the subsequent management with the impact of the well-known "recovery cost principle", highlighting the current difficulties in carrying out projects of this size, due to severe limitations, as social and economic conditions of the transfer.
\end{abstract}

Keywords: Water Transfer; Cost Recovery; Groundwater; Water Cost

\section{INTRODUCTION}

Unlike what happens in other neighboring countries like the United Kingdom [1] or even the OECD's recommendations for additional capital investments on into the urban infrastructures by institutional investors
[2], in Spain, public investment on water infrastructures such as water transfers remains essential.

Throughout history there has been a constant desire to provide the Vinalopó river basin in the south of the province of Alicante with external water supplies, matched by an equal desire to design initiatives to achieve this. The Júcar-Vinalopó water transfer, considered as an historic aspiration for many years in the region, has been regarded as a key element for solving the depletion of groundwater in a large area located in the southeast of the Iberian Peninsula. From an institutional and territorial point of view, these demands have largely been concentrated in the coastal areas, especially in the municipal area of Elche, although more recently Alicante has also started to request resources.

The beginning of the 20th century saw firstly the transfer of significant volumes of water to the coast, originating in the aquifers of the Villena area, and secondly, an increase in water transferred from the mouth of the River Segura by the irrigation companies of the area; El Porvenir, El Progreso and Riegos de Levante S.A.

The gradual drying out of the River Segura prompted the first projects related to the Tajo-Segura Water Transfer System ${ }^{1}$ at the end of the 1960s. Also at this time the towns of Alicante and Elche joined the Mancomunidad de Canales del Taibilla (MCT) ${ }^{2}$ (District Association of the Canales del Taibilla) in order to address the drinking

\footnotetext{
${ }^{1}$ The Tajo-Segura water transfer system, one of the largest in Spain, was initially designed to transport up to $600 \mathrm{Hm}^{3}$ per year from the centre to the south-east of the country, although only on one occasion, the water year of 2000/2001, was this maximum volume of water transferred. The General Preliminary Project of exploiting the TajoSegura contemplated a maximum volume of $600 \mathrm{Hm}^{3}$ per year "and it has been commented that in a second phase, a further $400 \mathrm{Hm}^{3}$ may be added.”

${ }^{2}$ The Mancomunidad de Canales del Taibilla (hereafter MCT) created in 1927, is a public body responsible for the high-level network supply to several towns in South-East Spain [3].
} 
water needs of a continuously growing population. Both circumstances relaxed the demands on the volumes originating in the Upper Vinalopó area for many years, and it was even suggested that the waters from the TajoSegura could alleviate the pressure on the aquifers of Vinalopó, contributing to balancing out the system.

However, the supplies from the Tajo-Segura were unstable (experiencing restrictions in supplies and irrigation for some years), the costs of extracting resources from the Vinalopó aquifers were lower than the rates applied by the MCT and there was a gradual increase in the extractions from the Vinalopó to be used for the extended irrigated land in the Upper and Middle areas of the Vinalopó. All of these factors gave rise to the reemergence of the historical demands, this time, from the inland towns of the area of the Vinalopó.

\section{THE JÚCAR VINALOPÓ WATER TRANSFER SYSTEM IN TERMS OF THE ECONOMICJUSTIFICATION OF PUBLIC INVESTMENT}

Do water transfer systems make sense from an economic point of view? Does the Júcar-Vinalopó Transfer System (JVT) make sense? What are the reasons that justify undertaking works of this size? If the existing literature agrees on anything in this field it is the discrepancy in both the alternatives to the problems raised and in the solutions.

This type of infrastructure is not new in Spain (the Tajo-Segura water transfer system, the largest in Spain, has been operating for more than 30 years), neither is the debate in terms of its appropriateness and whether it should be publicly financed [4]. Some authors provide support for the hypothesis that private infrastructure owners operate more efficiently than public ones [5].

In general terms, the public decisions regarding the creation of water transfer systems attempt to address the structural problems of receiving basins, where structural water problems are understood as those where ordinary needs and their provisions exceed current and forecast resources. Although this concept seems simple as a general criterion, contemplating it in Spain, where the distinction between a dry and wet Spain implies more than one variable, and where prices applied to water far from acknowledge the water scarcity indexes in each case, makes it a highly complex task.

But this question is not so far removed from the issue of costs and prices applied to the use of water. Can the crops in the receiving areas assume all the costs incurred by transferring water from one territory to another? If we only contemplate this variable (and set aside other issues such as environmental costs or the repercussions on ar- eas from where the water originates) - to what extend should the construction costs of the Transfer System be subsidised with public funds?

\section{THE FINANCIAL ECONOMIC PROBLEM OF THE JÚCAR-VINALOPÓ WATER TRANSFER SYSTEM}

Although the issues surrounding the need to supply the Vinalopó basin with external sources have been ongoing for some time, as previously mentioned, the conservation of the new areas transformed into irrigated land in the area since the 1960s is one of the key arguments for justifying the transfer project.

Nevertheless, while the problem of water resources imbalance and the overexploitation of the Vinalopó basin has predominantly been caused by private enterprises, although strongly promoted by public initiative [6,7], the solution to the problems basically lie in the hands of the public sector. Although this public involvement has not been a determining factor in the medium and long-term unsustainability of these systems ${ }^{3}$, it has been incapable of implementing limiting measures.

The fundamental milestone in the recent history of the Júcar-Vinalopó water transfer system was the Júcar Basin Plan in 1998 which not only sought to resolve the Vinalopó problem but also included the neighbouring area of Marina Baja as a water receiving area.

It should be taken into account that the authorities of the Marina Baja area responded to their own problem independently of the possible solution derived from the provision of external supplies from the Júcar. As already demonstrated [7,9], the action taken by the Consorcio de Aguas de la Marina Baja (CAMB) in the integrated management of all of its water resources has ensured that no external water resources are required to cover its needs ${ }^{4}$. However, the same does not apply to the Vinalopó basin. Neither the new organisations of users, nor the combining of uses has reduced the demand for external supplies. The State has also expressed its commitment to constructing the system, basically because it

\footnotetext{
${ }^{3}$ Neither the IGME [8] (Spanish Geological and Mining Institute) Reports during the 1970s that raised the need to adjust the uses to renewable resources of the water resource system of Vinalopó, nor the new Water Law of 1985, or the declarations regarding some overexploited aquifers forming part of this system (Sierra de Crevillente y Jumilla-Vilena) led to the incorporation of measures to resolve the problems, and are still not being developed today, 2011.

${ }^{4} \mathrm{~A}$ centralised management of the different resources and an internal compensations system between all the users has enabled the problems to be resolved with relatively low costs compared to those incurred by transferring external supplies. In practice, although there is still a demand for external resources, this demand corresponds to a safety margin to cover water needs in an extraordinary situation. It is for this purpose that external water is demanded, not for ordinary water needs.
} 
considers it to be essential for solving the problem of the overexploitation of the Vinalopó aquifers and partly because it fulfills the directives of the Júcar Basin Plan of 1999.

There are no common norms in terms of the financing of investments or the setting of rates to cover the operating expenses incurred in constructing the different hydrological infrastructure works in Spain. Therefore, on what parameters should the economic system be based in order to make the works feasible and sustainable in the long term? We will consider two aspects: the investment and operating expenses of the system and the payment capacity of users.

These terms are associated with the concept of "cost recovery" since the transposition of the European Water Framework Directive into Spanish legislation in 2003. However, its application in Spain has been irregular and vague. As different exceptions and interpretations of the law are used, a single criterion cannot be applied by the Spanish public authorities with respect to water resources so as to recover the cost of these operations. Different percentages of financing are distributed among users and authorities in a different way for each use with no known objective justifications other than the discretional power of the acting authority.

The action taken by Sociedad Aguas del Júcar S.A. (Table 1), the instrumental company that has carried out the construction works of the JVT, shows the extent to which different criteria are adopted for different actions, with no valid behavioural model for all types of action.

The inclusion of the Júcar Vinalopó Water Transfer Project in the Operational Programme for Valencia 2000-2006 [10] gave rise to the granting of European finance (ERDF Funds) for its construction, which reduced the costs attributable to the Central Government, with the level of private participation in applying this principle of cost recovery still to be determined. The Generalitat Valenciana (Regional Government of Valencia) also committed to carrying out the works of the Postrasvase (post transfer works), essential for the dis- tribution of water between all users, although without contemplating the participation of users in the financing or maintenance of this infrastructure, so the cost recovery principal in this case disappears with no explanation.

\section{PUBLIC SUPPORT AND FINANCING OF THE JÚCAR-VINALOPÓ TRANSFER SYSTEM FROM AZUD DE LA MARQUESA, THE NEW INTAKE LOCATION}

As in many other cases of public intervention in the economy, modifying the intake location of the JúcarVinalopó Transfer System from “Cortes de Pallás” to "Azud de la Marquesa” was not due to economic and financial reasons. Therefore, this alteration in the project did not rigorously contemplate the increase in investments that the new route required or the new operating expenses models of the system to maintain its sustainability.

The General Election of March 2004 and the subsequent change in government gave rise to a change in water policy in Spain, including the reconsideration of the transfer systems, even though the public works contracts for the different sections of the piping of the Júcar Vinalopó from “Cortes de Pallás” location to Villena had already been awarded to the corresponding contractors.

From the outset, the new government considered the modification of the National Hydrological Plan by eliminating the Ebro Transfer System and creating the new Water Programme through which it sought to satisfy the water demands principally in the Segura and Júcar basins by way of desalinating sea water and promoting reuse and making improvements in the management of hydrological resources.

The issue of the Júcar-Vinalopó Transfer became central to the debate in terms environmental questions and issues raised by user and irrigation organisations of the latter sections of the Júcar basin, which, until then had not been taken into account, together with the need to adopt the ruling of the Supreme Court of 2004 which modified the Júcar Basin Plan.

Table 1. Investments made by Aguas del Júcar S.A. (millions of €).

\begin{tabular}{|c|c|c|c|c|c|c|c|c|}
\hline \multirow{2}{*}{ infrastructure/financing } & \multicolumn{2}{|c|}{ Users Contributions } & \multicolumn{2}{|c|}{ AJS.A. Contributions } & \multicolumn{2}{|c|}{ European Funding } & \multicolumn{2}{|c|}{ Total \% } \\
\hline & Mill $€$ & $\%$ & Mill $€$ & $\%$ & Mill $€$ & $\%$ & Mill $€$ & $\%$ \\
\hline Júcar Vinalopó Water Transfer & 6960 & 3000 & 7650 & 3300 & 8580 & 3700 & 23200 & 100 \\
\hline Water supply system to Albacete & 440 & 1500 & 2460 & 8500 & & & 2900 & 100 \\
\hline Marina Baja Pipes & 190 & 2500 & 560 & 7500 & & & 750 & 100 \\
\hline Camp de Turia Irrigation Pipe & 1500 & 5000 & 1500 & 5000 & & & 3000 & 100 \\
\hline
\end{tabular}


The change in intake location also generated conflict with the Junta Central and altered the whole financing model which had been agreed with this organisation through the 2001 Agreement on 28/2/2005, which established:

1) The Syndicated Loan will not be awarded to cover the part corresponding to the users for the construction works of the Júcar-Vinalopó Transfer until the administrative and legal controversies regarding the availability of water to transfer from the Júcar that justifies the project are resolved. The forecast annual transferred volumes and their use (irrigation and supply) should be maintained at the levels stipulated in the Júcar Basin Plan and in the Agreement signed with AJSA on 13 July 2001. The content of the ruling (...) passed by the Supreme Courte on 20-10-2004 (...) advises that the syndicated loans should not be granted until the availability of the water resources for the Júcar-Vinalopó Transfer has been guaranteed through the corresponding legal provision.

2) To urge the modification of the Agreement signed with Aguas del Júcar S.A. so that the agreed contribution of the users is produced through pricing the water that is effectively received.

This new situation led the Ministry to modify the "Direct management agreement with respect to the construction and/or operation of hydrological works between MIMAM-Aguas del Júcar SA”. Modification No. 1 of March 2006, changed the financing system of the works, which from that moment and at the expense of the new contributions of the ERDF funds from the EU were distributed as follows: $26.4 \%$ with EDRF Funds (€80 million); $24.7 \%$ (€75 million, the same amount as in the preceding agreement) would be financed by Aguas del Júcar through a loan operation passed onto the users during the operation of the transfer through prices; and $48.9 \%$ of the cost of the activity (€148 million) would be financed through funds coming from the share capital of Aguas del Júcar.

The EC took the Decision on the $12 / 12 / 2006$ to modify both its final contribution to the "Júcar-Vinalopó Transfer" which increased to $€ 120,121,000$ (50\% of the total subsidisable cost), and the corresponding conditions, which were extended basically to ensure the effective improvement of the aquifer recovery in Vinalopó and the eastern part of Castilla-la Mancha, the resources supplied to the Júcar, the situation of Albufera and the savings in the traditional irrigated areas of the Júcar. It also proposed the creation of a technical monitoring group, dependent on the Monitoring Committee for the Operating Programme of the Region of Valencia [10], composed of representatives from the government, users, NPO and the Commission, in order to determine the degree of compliance with clauses of the Decision.

The greater participation from the EDRF funds reduced the contribution of Aguas del Júcar, which now amounted to $€ 108$ million. Also at that time the company calculated the operating expenses according to the following table, which show that the repercussion of the transferred water costs with average transferrable volumes of $70 \mathrm{Hm}^{3}$ was $€ 0.196 / \mathrm{m}^{3}$.

This calculation of costs transferred to the users is possibly one of the key elements in the ensuing discussions which have taken place in public debate. The most critical opponents of the change in intake location claimed that these calculations were unreal, especially those corresponding to energy costs, because with the new intake there are parts above sea level that must be overcome in order to carry the water from "Azud de la Marquesa” to the "San Diego" reservoir in Villena.

As the change in intake location to "Azud de la Marquesa” was rejected by the Junta Central, this organisation did not sign the new Agreement necessary for setting the new project into operation, which could lead to the absurd situation of carrying out infrastructure works that did not have any final users. During this period, Aguas del Júcar S.A. tried to sign individual contracts with final users of the water in order to ensure the existence of a demand for these resources, although only a few of them (including the Town Council of Elche or the Main Irrigation Channel of the Elche Reservoir, which are not represented by the Junta Central) signed these agreements.

The final solution to this dilemma was sought through the signing in January 2007 of an Agreement between the Júcar Hydrological Confederation (CHJ) and Aguas del Júcar S.A. which includes in its explanatory preamble: "That to facilitate the investment recovery of this project, the $\mathrm{CHJ}$, as the competent body responsible for the management of the hydrological resources of the Basin which it administrates does not oppose to being the intermediary between Aguas del Júcar S.A. and the final holders of the rights to use the transferred water, or the final users of the afore-mentioned project” [11-13]. In this way it is the CHJ who is obliged to assume the operating and conservation costs of the project, which subsequently recovers these expenses from the final users of the water.

\section{THE IMPLICATIONS ON FINANCING OF THE COSTS OF THE JÚCAR-VINALOPÓ WATER TRANSFER SYSTEM}

We have already seen that the change in the water intake location of the Júcar altered the whole balance 
which had been so painstakingly configured by the users of Vinalopó. It was not only a question of the different investment and operating costs derived from the new route (higher than the initial route). The final users were also altered, as the new model excluded the users of the water supply, eliminating the possibility of cross subsidies which would have financed the waters used for irrigation through the higher prices applied to water supplies. Although the former type of users would receive larger volumes of water, they would be at higher prices than in the initial project. That argument together with water prices that are many times set by water managers and, in some cases like the one we present here, politicians, the effectiveness of water prices as an instrument to rationalise water consumption is more than doubtful [14].

Furthermore, the new situation created the paradox whereby when water from the transfer was received for irrigation, resources would no longer be extracted from the Vinalopó aquifers, which would now be used for supplying water to the towns which would not have to finance works of the transfer project, even if this possibility remained open ${ }^{5}$.

One of the issues relating to the Júcar-Vinalopó Tranfser which is being tiptoed around is that referring to the prices which are to be applied to the consumption of the transferred water. This is not surprising, especially as the economic questions relating to water have always been characterised as being "less" important in almost all the public projects related to water management ${ }^{6}$.

However, since the approval of the European Water Directive of 2000 and the incorporation of the concept of "cost recovery", the panorama has partly changed. From this moment, all the institutions were now required to contemplate cost recovery in their budgets and if this could not be done then the reasons should be appropri-

\footnotetext{
${ }^{5}$ Despite the legal difficulty in creating a new financing model which contemplates the contributions of those users that indirectly benefit from the improvement of the state of the Vinalopó aquifers (especially the water supply users of the Vinalopó), the MIMAM included this possibility in the documentation submitted to the EC in 2005 in order to secure the financing of the project. As stated in the Supreme Court Ruling of $10 / 12 / 2009$, the grounds of the sixth point: "Precisely in the procedure processed by the Commission for the application of Community subsidies for the new route and to which the Decision refers, as indicated by the State Lawyer in processing the conclusions, it has always been stated that the objective of the Project is to palliate the overexploitation of the aquifers and to correct the deficit of water supplies, indicating that the great majority of the transferred resources will be for agricultural use, although this does not mean that there may be other beneficiaries. It was made clear to the EU's Directorate. General for Regional Policy, clarifying all doubts, that the arrival of the transferred waters would favour urban supply in the towns of the upper and middle areas of the Vinalopó and the environmental regeneration of the aquifers. Therefore, it was considered that the farmers who consumed the transferred water through supply rates and the entities with rights over the water as well as the users who continue to extract water from the aquifers should participate in the financing of the project.”
}

ately justified. However, what are these costs?

The EU Water Framework Directive distinguishes between operating expenses, environmental costs and resource costs. The first are defined as those costs related to extracting, piping and making water available to users. Environmental costs are those related to the operations necessary to ensure the conservation of environmental conditions through processes such as water treatment or aquifer recovery. However, in the case of resource costs or the opportunity costs of their use, there is no consensus with respect to the meaning of this concept [17].

Furthermore, the introduction of subsidies or privileged financing in terms of the interest rates applied or the repayment terms (in the case of the Júcar Vinalopó Transfer, the repayment terms are 35 and 50 years, while the repayment of the capital provided by Aguas del Júcar, SA is interest-free), makes it difficult to set objective criteria for the real efficiency of the projects and to determine which costs should be taken into account to establish the final total prices.

In the case of the Júcar-Vinalopó Transfer Project many of the previously-mentioned elements are present. Both in the current project from "Azud de la Marquesa" and in the previous one from "Cortes de Pallás", the economic restrictions have been regarded as a factor of secondary importance, after the ultimate objective which was and is to transfer water to the Vinalopó Basin for its subsequent distribution among users. We could sum up by saying that the real costs of the Transfer and Post Transfer infrastructure project and their operating expenses are highly conditioned by the political restrictions to which they are subject which means that the solutions must also be political.

It is useful to bear this in mind when seeking an explanation for the possible prices to apply and also to find a solution which makes its functioning feasible.

\subsection{The Issue of Water Costs According to Their Origin}

We have previously mentioned the repayment and operating rates of the JVT, contemplated in the 2007 Agreement between AJSA and the JHC. If we consider this point as being independent from the functioning of the whole system we run the risk that the Transfer will not work at all. The explanation is simple: the rates

\footnotetext{
${ }^{6}$ This comment is by no way unfounded. In the two reports sent to Brussels by the MMAMRM in 2007 and 2009 [15,16], despite the importance of this issue, the problem of rates or the prices of the water extracted from the aquifers are hardly mentioned. Neither do these reports analyse the question of how to resolve the compensations to the entities which will have to close their wells and substitute their resources with water from the Júcar-Vinalopó Transfer, desalinating plants or the reused treated water.
} 
passed on to the agricultural users in some years may reach 0.80 Euros per $\mathrm{m}^{3}$, including the repayment and operating costs, a figure that is way above the price of obtaining water through other methods and one which is unacceptable for irrigation.

In the following Table 2 we have made an estimate of these rates in accordance with the forecast of costs made by AJSA in 2006 for a Transfer of $70 \mathrm{Hm}^{3}$ (the operating costs are at this year's prices) and applying them to hypothetical transfers of between 10 and $50 \mathrm{Hm}^{3}$.

The actual prices for this system may be higher than the values obtained herein depending on variations in actual costs.

\subsection{The Implications of Reorganising Water Extractions in the Vinalopó Basin}

The Public Authorities responsible for water-related issues have always taken into account that in developing the Júcar-Vinalopó Transfer the transfer of resources should imply a reduction in the pressure on the Vinalopó aquifers and, therefore, the closing of many wells in the area. All of the reports and studies carried out in order to obtain European Commission funds have observed this question $[15,16,18,19]$

From a technical and hydrological point of view, the overexploitation of the aquifers may only be resolved by adapting extractions to replenishments, therefore, the optimum operating level would be that which produces a long-term equilibrium between the two. While some studies explore the possibilities that replenishing the aquifers would generate [8], this alternative would only work in situations when there was excess water and with the government assuming the costs of the whole opera- tion $^{7}$.

In the two projects contemplated ("Cortes de Pallás" and "Azud de la Marquesa"), the logic of the solution to overexploitation is the same: to reduce the pressure on the aquifers and increase their sustainability, although the ways of doing this have changed considerably.

In the Transfer Project from "Cortes de Pallás”, the water was to be used for both agriculture and urban supply (in the Vinalopó region, Alicante and the Marina Baja area), whereby the water that was no longer extracted from the closed wells was substituted by that from the Transfer at the prices agreed by the users and AJSA in $2001^{8}$. With respect to the Transfer Project from “Azud de la Marquesa”, the extractions for urban consumption are not replaced by the transferred waters as their quality is inferior, with resources generated by the desalinisation plants on the coast being used for this purpose, particularly those of Mutxamel and Alicante I and II. Although from a material point of view they may be equivalent, their costs can vary considerably. Furthermore, the negotiations for resolving these exchanges involve several Central Government bodies ${ }^{9}$; namely the CHJ and the Water Agency, ACUAMED and the MCT. While the former are concerned with harmonising the water rights of the users, the MCT are responsible for providing alternative supplies and closing wells and establishing consumer prices.

According to the Reports issued by the European Commission, the plans for closing wells have changed (Table 3).

As we can observe, the planned substitutions have risen from $65 \mathrm{Hm}^{3}$ for 2003 to $76.76 \mathrm{Hm}^{3}$ for 2007 and are calculated at $79.5 \mathrm{Hm}^{3}$ for 2009. These changes have not been explained in the ensuing reports.

Table 2. Costs transferred to the users of the Transfer.

\begin{tabular}{lcccc}
\hline & $\mathbf{7 0} \mathbf{~ H m}^{\mathbf{3}}$ & $\mathbf{5 0} \mathbf{H m}^{\mathbf{3}}$ & $\mathbf{3 0} \mathbf{H m}^{\mathbf{3}}$ & $\mathbf{1 0} \mathbf{H m}^{\mathbf{3}}$ \\
\hline Return of Investment (€/year) & $3,490,000$ & $3,490,000$ & $3,490,000$ & $3,490,000$ \\
Energy (€/año) & $7,351,449$ & $5,251,035$ & $3,150,621$ & $1,050,207$ \\
Turbine stations incomes (€/year) & 711,030 & 507,875 & 304,725 & 101,575 \\
Conservation and maintenance (€/year) & $3,559,867$ & $3,559,867$ & $3,559,867$ & $3,559,867$ \\
Total exploitation costs (€/year) & $10,200,286$ & $8,303,027$ & $6,405,763$ & $4,508,499$ \\
Total retroceded costs (€/year) & $13,690,286$ & $11,793,027$ & $9,895,763$ & $7,998,499$ \\
Retroceded Costs $\left(\mathrm{Hm}^{3} /\right.$ year) & 0.20 & 0.23 & 0.33 & 0.80 \\
\hline
\end{tabular}

\footnotetext{
${ }^{7}$ Although it may seem far removed from reality, this situation could arise if the possibilities of transferring water from the Júcar were higher than the irrigation demands in the area. In this case, these studies would be useful to ascertain which aquifers could store this water which could be subsequently used. The issue of the costs (which in this case are double due to the Transfer rates and the cost of its construction) and quality would determine the feasibility of the operation.

${ }^{8}$ It should be noted that these rates are out of date, although they are still used as a reference.

${ }^{9}$ Part of this problem has been eliminated with the integration of AJSA into ACUAMED in 2010.
} 
Table 3. Programmed well closures 2003-2007 in the Vinalopó-Alacantí System.

\begin{tabular}{lcc}
\hline $\begin{array}{c}\text { Vinalopó Alacantí System. } \\
\text { Hydrogeological Units }\end{array}$ & $\begin{array}{c}\text { 2003 Replacement Proposal } \\
\left(\mathbf{H m}^{3}\right)\end{array}$ & $\begin{array}{c}\text { 2007 Replacement Proposal } \\
\left.\mathbf{H m}^{3}\right)\end{array}$ \\
\hline 32. Sierra Grossa & 0.32 & 0 \\
33V Almansa & 0 & 0.02 \\
34. Sierra Oliva & 0 & 20.64 \\
35. Jumilla-Villena & 15.00 & 17.21 \\
36. Villena-Benejama & 16.50 & 2.83 \\
40. Sierra Mariola & 1.35 & 2.59 \\
41. Peñarrubia & 4.50 & 6.14 \\
42. Carche-Salinas & 6.50 & 1.64 \\
43. Argueña-Maigmó & 4.00 & 0.11 \\
44. Barrancones-Carrasqueta & 0.86 & 0 \\
48. Orcheta & 0 & 0.07 \\
49. Agost-Monnegre & 0.45 & 1.65 \\
50. Sierra del Cid & 1.00 & 3.23 \\
51. Quibas & 3.60 & 10.27 \\
52. Crevillente & 10.07 & 9.39 \\
99. Impermeable & 0.85 & 76.76 \\
Total & 65.00 & \\
\hline
\end{tabular}

Source: $[19,20]$

The 2009 Report [15] highlights the implications of these substitutions for both agricultural uses and supply uses with the latter reaching $27.8 \mathrm{Hm}^{3}$. If we take into account that the Transfer waters are not appropriate for human consumption and therefore the towns of the Upper and Middle Vinalopó areas continue to extract underground water for this use, practically all of the substitutions will correspond to what has been called "water exports" to the coast and especially to the wells of Aguas Municipalizadas de Alicante, The Local Government of Elche (through its contract with Finca Los Frutales) and Sociedad Canal de la Huerta de Alicante S.A.

The change in costs produced by substituting the water from the aquifers, whose prices vary between 0.20 and $0.30 € / \mathrm{m}^{3}$, with those obtained through theses alternative supplies on the coast is considerable. With 2008 data, we have included the rates applied by the MCT, which were $0.5446 € / \mathrm{m}^{3}$ and the costs which the same organisation estimates that the different desalinisation plants that it manages, which in the case of Alicante reached $0.70 € / \mathrm{m}^{3}$.

The new situation will bring with it a considerable increase in the prices charged to final users in the towns on the coast, which are currently supplied, in part, by the water from the Vinalopó aquifers. The case of Sociedad Canal de la Huerta S.A. is special because its hydrological resources should only be used for agricultural con- sumption.

According to this model, the towns that would benefit are those of the Upper and Middle areas of the Vinalopó, because due to the lack of other alternatives they will continue to be supplied by their wells, and at the same time their water masses will improve with the reduction in extractions of water for irrigation (which is substituted for the transferred water) and the extractions used to supply the coast will disappear.

\section{CONCLUSIONS}

Without doubt, the implementation of the Júcar-Vinalopó Transfer system will represent an historical milestone in terms of water in the south of Alicante. The transformation of the traditional aspirations of a specific project has been surrounded in controversy, which is evident in the decisions that have been taken in recent years to this respect.

The issues relating to the appropriateness of one intake location or another in the Júcar will take second place to the need to specify how its water is to be shared, how the costs are to be distributed and how all the resources and uses are to be organised in such a complex hydrological system.

The new challenges that have arisen are also related to the coordination of the different agents that operate in this field and the need for them to be capable, with a 
maximum level of responsibility, to obtain the highest profitability from this project and share the profits and the costs equally.

The final solution will not be easy, especially due to the enormous politicization that the hydrological issues in this region have acquired. However there is no doubt that the questions related to the costs and prices that are finally applied will be decisive for a possible solution.

\section{REFERENCES}

[1] OFWAT (2007) The completed acquisition of Thames Water Holdings Plc by Kemble Water Limited. A Position Paper by Ofwat, London.

[2] Torrance, M. (2009) Reconceptualizing urban governance through a new paradigm for urban infratructure Networks. Journal of Economic Geography, 9, 805-822. doi:10.1093/jeg/lbn048

[3] Taibilla Channels Association (2009) Annual Report 2008. http://www.mct.es/

[4] Molina, A. (2010) Spanish water transfers regulations. Diario La Ley, 7366, 15-17.

[5] Megginson, W.L. and Netter, J.M. (2001) From state to market: A survey of empirical studies on privatization. Journal of Economic Literature, 39, 321-389. doi:10.1257/jel.39.2.321

[6] Sevilla, M., Torregrosa, T. and Moreno, L. (2010) Groundwater and the tragedy of the commons in El Vinalopó. Estudios de Economía Aplicada, 28, 302-322.

[7] Torregrosa, T. (2009) Water management in the region of the Marina Baja (Alicante). Topics of the Valencian Parliament, 19, Cortes Valencianas, Valencia.

[8] IGME (2004) Potential storage possibilities of the JúcarVinalopó waters in provincial underground reservoirs through artificial recharge. Simulation of water resources management in the Medio Vinalopó. IGME and Provin- cial Council of Alicante, Madrid.

[9] Torregrosa, T. and Sevilla, M. (2010) A socioeconomic model for managing water resources in Alicante, Southeast Spain. Water International, 35, 442-455. doi:10.1080/02508060.2010.506258

[10] Valencian Regional Government GVA (2000) Operational integrated programme for Valencian Region 20002006. ESF, Economic Affairs Department, Valencian Regional Government, Valencian.

[11] Aguas del Júcar SA (2001) Agreement between the users of the Júcar-Vinalopó and AJSA. General Assembly of the CGU-Medio Vinalopó and Alacantí and the Alto Vinalopó CGU.

[12] Central Board of Vinalopó and l’Alacantí and Marina Baja Water Consortium Users (2002) Statutes. Http://juntacentral.es/sobre.htm

[13] MMA (2007) CHJ and AJSA Agreement. Ministry on Environment, Spanish Government, Madrid.

[14] Olmstead, S.M. (2010) The economics of managing scarce water resources. Review of Environmental Economics and Policy, 4, 179-198. doi:10.1093/reep/req004

[15] River Júcar Hydrological Demarcation (CHJ) (2009) Report on the status of the Article 2 conditions. CHJ.

[16] River Júcar Hydrological Demarcation (CHJ) (2007) Monitoring of Jucar River basin management plan: Synthesis. Water Planning Office.

[17] MMA (2004) Continental water on the European Union. CEDEX MMA, Madrid.

[18] River Júcar Hydrological Demarcation (CHJ) (2009) Methodology and results of the demands estimations. Technical Reference Paper, Territorial Area of the River Júcar Hydrological Demarcation, CHJ.

[19] River Júcar Hydrological Demarcation (CHJ) (2003) EIB response report on JV infrastructures. CHJ.

[20] River Júcar Hydrological Demarcation (CHJ) (2007) Júcar-Vinalopó. Report on the Status of the Article 2 Conditions, CHJ. 